\title{
情報界のトピッワス
}

\section{「米国デジタル公共図書館」計画のイニシア チブ開始}

ハーバード大学の研究プログラムであるBerkman Center for Internet and Societyは，アルフレッド・P・ スローン財団からの資金を受けて「米国デジタル公 共図書館」(Digital Public Library of America) 設立に 向けた研究・計画のイニシアチブを開始することを 2010年12月13日に発表した。Berkman Centerの共同 ディレクターPalfrey教授は，「狙いは，多くの人々が 公共心に富む解決に向けて熱心に取り組むための大 きなテントを作り出すことであり，競争的な運動で はない」と語っている。今後「米国デジタル公共図 書館」計画に関わるさまざまな関係者グループを集 め，カバ一領域，構成，コスト，管理・運営などを 規定していく。計画作成の活動は，Palfrey教授を委 員長とする運営委員会により，2011年早々に発表さ れるが，教育界，公共図書館，研究図書館，文化団 体，政府，地方自治体，出版社，著作者，民間企業 からの代表を集めて会議やワークショップを開催し， オンライン資源へのパブリックアクセス改善の戦術 を検討する予定である。米国国立公文書館のDavid Ferriero館長が，2011年夏に関係者を集めた全体会議 を主催することを提案しているほか，法律，コンテ ンツ，技術，財政，ガバナンスに関するコンセンサ スを形成するために，5つのワークショップも開催さ れることになっている。また，議会図書館，米国国 立公文書館，スミソニアン協会の3団体はすでに，自 分たちの所蔵するデジタルコレクションへのアクセ スを可能にするための協議や協力活動を開始済みで ある。
「米国デジタル公共図書館」のアイデアが具体化さ れたきっかけは，ハーバード大学図書館長でもある Pforzheimer大学のRobert Darnton教授が昨年10月に 開催した私的な会議である。研究図書館, 主要な財 団，国立の文化研究所から42名が出席し，国立デジ タル図書館設立に向けてどうのように協力すべきか が検討された。当時はファンタジーのように思われ た構想がわずか2か月で実現化へ向けて動き出したも のである。Darnton教授の考えは，参加大学図書館 や議会図書館のような文化機関が所蔵する電子資源 をリンクさせ，一つのポータルからアクセスできる ようにすることにあり，Google Booksに対する非営 利機関の代替策であるととらえている。イニシアチ ブの運営委員会構成メンバー12名には，Darnton教 授も含まれ，そのほか米国・図書館情報資源振興財 団 (Council on Library and Information Resources) のCharles Henry会長，議会図書館のDeanna Marcum 氏，メロン財団のDonald Waters氏，スローン財団の Doron Weber氏など，図書館と財団の指導者が名を 連ねている。 (http://cyber.law.harvard.edu/newsroom/digital_ public_library)(http://www.libraryjournal.com/lj/co mmunityacademiclibraries/888496-419/new_plan_ seeks_a_big.html.csp)(accessed 2011-01-14).

\section{Books at JSTOR計画}

学術ジャーナルのバックナンバーを提供してきた JSTORは，電子ブックビジネスに乗り出すことを，米 国図書館協会の2011年冬季大会で正式に発表した。 「Books at JSTOR」と名づけられたこのプログラムは， 
大学出版局の既刊本と新刊本を，世界中の図書館に 提供するもので, 出版社, 図書館, 学術コミュニティー のニーズを1年間にわたって調査研究した結果として 生み出されたものである。発表によれば，対象とな る電子ブックは，JSTORのデータベースに含まれる 学術ジャーナルと統合され，横断検索が可能となる だけでなく，200万件の書評やジャーナル論文中の何 十万ものレファレンス文献にリンクが張られる。同 一著者による文献や同じ主題の文献は，形式に関わ らず，関連付けられて利用者にアラートサービスが 提供される。電子ブックはすべて，図書館，出版社， 財団の協力の下に66,000を超える電子ブックを保管 している米国の電子ジャーナルアーカイビング事業 Porticoに保存されることになる。「Books at JSTOR」は， JSTORのビジョンや協力精神，価值観を共有する限 りは，営利·非営利を問わずすべての出版社に開かれ る。現在, プリンストン大学, エール大学, シカゴ大学, ミネソタ大学，ノースカロライナ大学の5つの出版局 との契約が結ばれており，カリフォルニア大学，ハー バード大学，MITの出版局とは協議中で，その他の大 学出版局とも話し合いが行われている。

(http://about.jstor.org/news-events/announcementarchive/books-jstor)(accessed 2011-01-14).

\section{米国のインターネット利用者の3分の 2 が有料 コンテンツを利用}

非営利団体Pew Research CenterのInternet \& American Life Projectが，2010年10月28日〜11月1日 に行った調査結果を2010年12月30日に発表した。報 告書によると，米国のインターネット利用者の65\% がコンテンツのダウンロードやアクセスのために料 金を支払っている。最も多く利用しているのは音楽 (利用者の $33 \%)$ ，ソフトウェア (同33\%)，携帯電 話やタブレットPC用のためのアプリケーション（同 21\%）で，デジタル新聞・雑誌・雑誌論文・レポー トに料金を支払つたのは利用者の $18 \%$ ，電子ブック
に料金を支払つたのは利用者の10\%であった。利用 料金の平均值は1か月47ドルだが，特に高額の利用 者を除いた標準的な利用者の1か月あたり利用金額は 10 ドルで，23\%の利用者が定期購読サービスを利用 している。有料コンテンツ利用者と非利用者を比べ ると，男女間には差が無く，30～49歳の年齢グルー プが最も有料コンテンツを利用している。学歴で見 ると，より多く有料コンテンツを利用しているのは 高卒者よりも大学生/大学卒業生である。調査期間 中に有料コンテンツを利用しなかった $35 \%$ の人々は， 白人よりも非白人，若者よりも50歳以上の人々の割 合が高いことも判明した。

(http://www.pewinternet.org/Reports/2010/Payingfor-Content/Overview.aspx)(accessed 2011-01-14).

\section{「デジタル海賊版」配信で出版4団体がアップ ル社に要請文}

2010年11月上旬，アップル社のiPhoneやiPad向け アプリケーション販売サイト「App Store」で，村 上春樹氏や東野圭吾氏などの作品のデジタル海賊版 が販売されていることが判明した。この問題に関し て，日本書籍出版協会，日本雑誌協会，日本電子書 籍出版社協会，デジタルコミック協議会の出版4団 体は2010年12月14日，アップル社に対して連名の要 請文を発表した。4団体は，明白な著作権侵害物であ るデジタル海賊版を配信することは違法行為の幇助 にあたると指摘し，アップル社の責任を指摘。アッ プル社が著作権の事前チェックは不可能であり行う つもりがないと主張している点についても，著作内 容の事前審査は行いながら，明白な著作権侵害行為 をチェックできないとは到底納得できないとしてい る。さらに，デジタル海賊版の削除要請空口や削除 手順も明示されていないこと，アップル社がデジタ ル海賊版から利益を得ているにもかかわらず，その 販売データを開示していないなど，アップル社の対 応を非難している。4団体は，こうした情報の開示と 
防止策の構築をアップル社に対して求めている。 (http://www.jbpa.or.jp/pdf/documents/ applepress1214.pdf)(accessed 2011-01-13).

\section{5年までにデジタル教科書普及へ}

デジタル教科書教材協議会（DiTT）は2010年12月 10日，学校教育におけるデジタル教科書教材普及に 向けた「DiTTアクションプラン」を発表した。2015 年までのデジタル教科書普及達成を民間目標とし， 2020年の普及達成を目指す政府目標を5年前倒しし た。具体的には，2015年までの目標として，1）日本 の全小中学生に情報端末を配布，2）全教科のデジタ ル教材を開発，3）全授業のうち約3割での利用，の3 つを定めている。デジタル教科書教材協議会は2010 年，すべての小中学生がデジタル教科書教材を持つ 環境の実現を目指して設立された。教科書会社のほ か，出版社，放送局，ゲーム会社など110社が参加し て，課題整理，政策提言，ハード・ソフト開発，実 証実験および普及啓発を行っている。

(http://ditt.jp/news/1213)(accessed 2011-01-13).

\section{5年のIT市場予測}

野村総合研究所（NRI）は2010年12月17日と20日， 国内を中心とする2015年度までのIT主要市場の分析 と規模予測の結果を発表した。分析対象は，1）ブロー ドバンド関連サービス，2）放送メディア，3）ネッ トビジネス市場，4）モバイル，5）ハードのIT主要5 市場。この予測では，ブロードバンド回線の世帯普 及率が2015年には約7割に達するとしている。また電 子書籍コンテンツ分野は，2010年から2015年までの 5年間に年平均 $23.1 \%$ 成長し，2015年には2,400億円 市場になると予測した。電子書籍端末は2015年には 1,400万台になるとしている。NRIのIT市場予測は2000 年以降毎年行われており，今回が10回目。 (http://www.nri.co.jp/news/2010/101217.html) (http://www.nri.co.jp/news/2010/101220.html) (accessed 2011-01-13).

\section{「Google Books Ngram Viewer」公開，書籍の} 使用単語を分析

Googleは2010年12月16日，Google Booksの全書籍 データ内での単語・成句の使用頻度を表示するツー ル「Google Books Ngram Viewer」を発表した。こ のツールでは，Google Booksでスキャンした1,500万 点以上の書籍のうち，500万点以上の書籍データを分 析し，その中の約5,000億の語句の使用頻度を表示で きるようになっている。単語や成句（5語まで）と対 象期間（1500年から2008年までの任意の期間）を入 力すると，指定した語句の使用頻度を折れ線グラフ で表示する。複数の語句の使用頻度を比較すること も可能。英語のほか，アメリカ英語，イギリス英語， 英語フィクション，中国語（簡体字），ロシア語，ス ペイン語、フランス語, ドイツ語という言語・カテ ゴリを指定して検索することもできる。

(http://googleblog.blogspot.com/2010/12/find-outwhats-in-word-or-five-with.html)(http://ngrams. googlelabs.com/)(accessed 2011-01-13).

\section{高齢者層のSNS利用が広がる}

米国の調査団体ピュー・リサーチ・センターが 2010年12月16日に発表したインターネット利用に 関する世代別調査の結果で，インターネットの利用 があらゆる世代に広がっていることが明らかになっ た。18歳から33歳の年代は，特にソーシャルネット ワークサイト (SNS) やインスタントメッセージ， オンラインゲームの利用でほかの年代を上回ってい る。しかし，34歳から45歳の年代では，政府Webサ イトの閲覧や金融情報の入手などでは18歳から33歳 の年代よりも利用頻度が上回った。電子メール利用 や医療情報の入手，ショッピング，旅行の予約や才 
ンラインバンキングなどの利用は，年代による差が なくなっている。74歳以上の年代によるSNSの利用は 2008年の4\%から16\%に急増しており，高齢者層のイ ンターネット利用も進んでいることがわかる。この 結果は，2010年4月から5月にかけて，米国の18歳以 上の大人 2,252 人を対象とした電話調査の結果に基づ いている。

(http://www.pewinternet.org/Reports/2010/

Generations-2010.aspx)(accessed 2011-01-13).

\section{電子書籍リーダ一認知度，「ガラパゴス」が健闘}

オンラインメディアのインターネットコムは1月 11日，電子書籍販売サイトとリーダー端末に関する オンライン調査の結果を発表した。全国の10代から 60 代以上の世代のインターネットユーザー1,079人
を対象とした調査では，「電子書籍がどのようなもの か知っている」と答えた回答者が全体の約64\%だっ た。「知っている」と答えた回答者に，知っている電 子書籍リーダー端末を聞いたところ，「GALAPAGOS」 (シャープ) が53.6\%, 「Kindle」(Amazon) が53.1\%と， 圧倒的な地位を築いているとされるKindleに対して， 最近発売されたばかりのGALAPAGOSが認知度の面で は肩を並べていることがわかった。電子書籍販売サ イトでは,一般書籍の販売でも知名度の高い「amazon. com」(46.5\%) の認知度が最も高かった。一方で,「ど れも知らない」と答えた回答者も $40.5 \%$ い。同調査 では，電子書籍販売サイトはまだアーリーステージ にあり，シェア争いが本格化するのはこれからだと している。

(http://japan.internet.com/research/20110111/1. html)(accessed 2011-01-13). 